\title{
Pasting and functional properties of lafun and starch processed from some improved cassava genotypes in Nigeria.
}

\author{
Omodamiro, R.M ${ }^{*}$, Iwe, M.O ${ }^{2}$ and Ukpabi, U.J. ${ }^{1}$ \\ ${ }^{1}$ Biochemistry Programme, National Root Crops Research Institute, Umudike; \\ ${ }^{2}$ Department of Food Science and Technology, \\ Michael Okpara University of Agriculture, Umudike, P.M.B. 7267, \\ Umuahia, Abia State, Nigeria. \\ *Address for correspondence
}

ABSTRACT

\begin{abstract}
Twenty eight cassava genotypes resistant to the dreaded cassava mosaic disease were randomly selected from the National Root Crops Research Institute Umudike, farm. The cassava samples were processed into starch and lafun, and their pasting and functional properties were assessed. Also amala was obtained from the lafun and examined for sensory characteristics of smell, hand feel (stickiness), appearance and general acceptability. Results show that the pasting properties (gelatinization temperature, Peak viscosity, Viscosity at $92^{\circ} \mathrm{C}$ after $15 \mathrm{~min}$ of heating and Stability) fell within reported values. The values ranged from 1020 BU for sample 95/0166 to $2500 \mathrm{BU}$ for samples 98/2101, TMS 96/1565 and TME 419. The peak viscosity of the lafun samples ranged from 920 BU for sample 95/ 0166 to 2500 BU for samples 96/1089, 98/0068, TMS 96/ 1565, 94/0561 and M98/0068. The value of the peak
\end{abstract}

viscosity of the starch sample was higher than that of the lafun sample in most cases. Bulk density of the starch samples ranged from $1.43 \mathrm{~g} / \mathrm{cm}^{3}$ for TMS97/22053 to $33 \mathrm{~g} /$ $\mathrm{cm}^{3}$ for M98/006. On the other hand, the Bulk density of the lafun samples ranged from $0.08 \mathrm{~cm}^{3}$ for TMS $96 / 1565$ to $1.96 \mathrm{~cm}^{3}$ for TMS 92/0067. Water absorption capacity of the starch samples ranged from $0.5 \mathrm{~g} / \mathrm{ml}$ for samples TMS 98/2101 and 99/3073, to 2.0g/ml for sample TMS 98/0510. The values for the lafun samples ranged from $0.5 \mathrm{~g} / \mathrm{ml}$ for TMS 99/2123 to $2.5 \mathrm{~g} / \mathrm{ml}$ for TMS 30572. All the samples were on the average acceptable to the panelists having scored an average of 4.00 on a scale of 7.

Key words: Cassava genotypes, resistant to cassava mosaic disease, functional properties, sensory evaluation.

\section{INTRODUCTION}

$\mathrm{C}^{\mathrm{a}}$ assava (Manihot esculenta Crantz) is a cyanogenic plant of great importance in the nutrition of over eight hundred million people in the tropical world. More than one hundred people obtain $500 \mathrm{Kcal}$ per day from cassava (Bokanga and Otoo, 1994). In Central Africa, cassava is estimated to provide over $1000 \mathrm{Kcal}$ per day to 30 million people (Cock, 1985).

The consumption of cassava has currently been on the increase, and the growing of cassava is expanding to semi-arid areas where cassava was not cultivated some thirty years ago. The adoption of disease- and pest-resistant varieties released by the International Institute for Tropical Agricultrue (IITA), Ibadan and the National Root Crops Research Institute (NRCRI), Umudike, have increased cassava production in many African countries, to such an extent that Nigeria has become, since 1989, the largest cassava producer in the world (Bokanga and Otoo, 1994; FAO, 1991; FAO STAT, 2002). The current production figures of cassava in Nigeria is about 34 million metric tonnes per annum. 
New cassava Genotypes are regularly being bred and assessed and selected by the IITA, Ibadan and NRCRI, Umudike for high yield, and resistance to pests and diseases, with a particular reference to the most dreaded cassava mosaic disease (CMD).

Current efforts have been geared towards breeding CMD resistant varieties, which are being evaluated at the relevant research institutes.

In Nigeria the fresh starchy cassava roots which do not store for up to one week are largely processed and used as human food, animal feed and industrial starch (Ejiofor and Ukpabi 1997). One of the major processing indices of the cassava tuber is its ability to gelatinize and form thick pastes for human consumption. The gelatinization process is a property of the starch granule found in cereals and tuber crops (Iwe et al., 1999). The Brabender amylograph has been the equipment of choice in the study of gelatinsation process, which is reflection of the rheological and functional characteristics starches in food systems (Iwe et al., 1999). Starch and Lafun, are some of the major products of cassava processing in Nigeria, which deserve investigation, with particular reference to the CMD. The present study was carried out to investigate the behaviuor of starch and lafun produced from the new CMD resistant varieties to gelatinization.

\section{MATERIALS AND METHODS}

The twenty eight cassava genotypes used for this study were obtained from Cassava Programe, NRCRI Umudike. Except for NR 8082, TMS 30572, and TMS 4(2) 1425 the remaining twenty five genotypes were newly selected for resistance to CMD by IITA in collaboration with NRCRI.

\section{Preparation of products.}

Cassava roots used for the study were harvested at 12 months after planting. The unit operations adopted for lafun production included peeling, washing, chucking, soaking /fermentation, washing, dehydration, milling and sieving; while for starch production it included peeling, washing, rasping, sieving, sedimentation, decantation, drying and milling.

\section{Determination of Pasting and functional properties.}

Brabender Amylograph was used to determine the pasting characteristics (Iwe et al., 1999). Gelatinization temperature, peak viscosity, viscosity at $92^{\circ} \mathrm{C}$, after $15 \mathrm{~min}$ and stability were deduced following the report of Adeyemi et al. (1992). The functional properties investigated included water absorption capacity (WAC), Oil absorption capacity (OAC) and bulk density (BD) (Okezie and Bello, 1988; Iwe and Onuh, 1992, Iwe, 2003).

\section{Sensory evaluation}

Sixteen lafun samples were randomly selected for the sensory evaluation among those with high, medium and low viscosity (with TMS 30572 as control). Sensory evaluation of "amala" produced from the Lafun samples, was effected by twenty five semi-trained panelists, for hand feel, appearance, texture and general acceptability. Scoring was done with a 7-points Hedonic scale (1-7) where 1 represented "Dislike extremely", 4 represented "Neither like nor dislike" and 7 represented "like extremely" (Iwe, 2002)

\section{RESULTS AND DISCUSSION}

The gelatinization temperatures of starch and lafun samples are shown in Table1. Results show that there were significant differences $(\mathrm{p}<0.05)$ in the gelatinization temperature of the starch and lafun samples processed from the CMD resistant cassava genotypes. Gelatinization temperatures of the starch samples ranged from $64.5^{\circ} \mathrm{C}$ for sample 99/3073 to $74^{\circ} \mathrm{C}$ for sample $99 / 2123$. On the other hand, the gelatinization temperature of lafun ranged from $69^{\circ} \mathrm{C}$ for sample $99 / 3073$ and $80^{\circ} \mathrm{c}$ for sample 99/ 2123. The ease of gelatinization is a reflection of the nature of starch or the level of contamination of starch (Iwe et al., 1999). It is clear from these results that the starch samples had lower gelatinization temperature compared to the lafun samples, 
probably due to the high content of fiber in the lafun sample.

Results of the Peak viscosity of the cassava samples are shown in Table 1. There were significant differences in the Peak viscosity values of the starch samples. The values ranged from $1020 \mathrm{BU}$ for sample 95/0166 to 2500 BU for samples 98/2101, TMS 96/1565 and TME 419. The peak viscosity of the lafun samples ranged from $920 \mathrm{BU}$ for sample 95/0166 to 2500 BU for samples 96/1089, 98/ 0068, TMS 96/1565, 94/0561 and M98/0068. As expected, the value of the Peak viscosity of the starch sample was higher than that of the lafun sample in most cases. It is not clear why sample 98/2101 had a lower Peak viscosity of 996 BU. Published reports had shown that the peak viscosity of pure starch is higher than those of non-pure starch. Oguntunde (1987) reported that the associative bonding of the amylose fraction is responsible for the structure and pasting behaviour of starch granule. The viscosity or more correctly the consistency of a cooked starch paste simply reflects the resistance to stirring of the swollen mass gel particles.

Results of the viscosity of the starch at $92^{\circ} \mathrm{C}$ after 15 min of heating are shown in Table 1. Values for the starch samples ranged from $310 \mathrm{BU}$ for sample $92 \mathrm{~B} / 0068$ to $890 \mathrm{BU}$ for TMS 96/1565. The value of $310 \mathrm{BU}$ recorded for sample 92B/0068 is rather lower than the range of value of $800 \mathrm{BU}$ earlier reported for cassava starch by Adeyemi $e t$ al. (1992). On the other hand, values for the lafun samples ranged from $165 \mathrm{BU}$ for $98 / 2101$ to 960 BU for TMS 4(2) 25 . The low value for $98 / 2101$ cannot be explained. However, the values for the lafun samples are generally higher than those of the starch samples, showing that the samples have higher consistency during shearing, due to the presence of fiber. Adeyemi et al. (1992) and Iwe et al. (1999) showed that viscosity of samples at $92^{\circ} \mathrm{C}$ after 15 min of heating is an indication of the consistency of the samples.
Results of the stability of the samples are shown in Table 1. Values for the starch samples ranged from $180 \mathrm{BU}$ for sample $94 / 0026$ to 2190 for $92 \mathrm{~B} / 0068$. There were significant differences $(\mathrm{P}<0.05)$ in the values of the stability of the samples. Values for the lafun samples ranged from $235 \mathrm{BU}$ for $95 / 0166$ to 2164 BU for TMS 98/0068. The lower values are much lower than the value of $1500 \mathrm{BU}$ reported by Adeyemi et. al. (1992) for cassava starch. Generally, the values obtained in this work favourably compare to those earlier reported in the literature. The stability of the cassava starch and those of lafun are comparable.

Results of the functional properties of the samples are shown in Table 2. There were significant differences in the functional properties of the starch and lafun samples. Bulk density of the starch samples ranged from $1.43 \mathrm{~g} / \mathrm{cm}^{3}$ for TMS97/22053 to $33 \mathrm{~g} /$ $\mathrm{cm}^{3}$ for M98/006. On the other hand, the Bulk density of the lafun samples ranged from $0.08 \mathrm{~cm}^{3}$ for TMS 96/1565 to $1.96 \mathrm{~cm}^{3}$ for TMS 92/0067. The low results obtained for TMS 96/1565 cannot be explained. The variation in Bulk density should as a result of the variation in starch content. Earlier reports (Iwe and Onuh, 1992 and Iwe and Onadipe, 2001) indicate that starch content increases Bulk density. This situation might also explain the low values of bulk density obtained for lafun samples in this work.

The Oil absorption capacity values of the starch samples range from $1.0 \mathrm{~g} / \mathrm{ml}$ for TMS 4(2) 1425 to $2.5 \mathrm{~g} / \mathrm{ml}$ for TMS 99/2123. On the other hand the Oil absorption capacity valuyes of the lafun samples ranged from $1.5 \mathrm{~g} / \mathrm{ml}$ for TMS 30572, 96/1089, 99/ 3073, 94/0026, TME 419, TMS 97/4779, 96/0603 and TMS 92/0067. The Oil absorption values of the samples were respectively significantly different $(\mathrm{P}<0.05)$. Oil absorption values of the lafun samples were higher than those of the starch samples for obvious reasons. Oil absorption increases with increase in fiber in food systems (Iwe and Onadipe, 2001). 
Values of the Water absorption capacity of the samples are shown in Table 2. There were significant differences in the Water absorption capacities of the starch as well as the lafun samples. Water absorption capacity of the starch samples ranged from $0.5 \mathrm{~g} / \mathrm{ml}$ for samples TMS 98/2101 and 99/ 3073 , to $2.0 \mathrm{~g} / \mathrm{ml}$ for sample TMS 98/0510. TMS 98/0510 had very high Gelatinization temperature as well as Peak viscosity values. The values for the lafun samples ranged from $0.5 \mathrm{~g} / \mathrm{ml}$ for TMS 99/ 2123 to $2.5 \mathrm{~g} / \mathrm{ml}$ for TMS 30572. TMS 30572 equally had reasonably high values of Gelatinization temperature as well as Peak viscosity. Water absorption capacities of food systems increase with increase in solutes. Increase in Water absorption capacity in food systems enables bakers to manipulate the functional properties of dough in bakery products (Achinewhu and Orafun, 2000; Iwe and Onadipe, 2001). CMD resistant samples with high level of water absorption capacity will be useful in meeting the expectation of the current Presidential Cassava Initiative for the bread industry in Nigeria.

Results of the sensory evaluation of the amala prepared from lafun samples is shown in Table 3. There were significant differences $(\mathrm{p}<0.05)$ in the smell, hand feel, appearance and the general acceptability of the amala samples. TMS 94/0039 consistently had higher ratings in smell, hand feel, appearance and general acceptability. Sample NR 8082 had the lowest value for smell. Sample 99/ 3073 had the lowest value for hand feel, while samples 98/2101 and 96/1565 had the lowest scores for appearance and general acceptability respectively. All the samples were on the average acceptable to the panelists having scored an average of 4.00 on a scale of 7.

\section{CONCLUSION}

Results of the evaluation of the pasting properties show that there were significant differences in the pasting properties of the starch samples from different cassava genotypes. A similar result was obtained for lafun samples processed from the CMD resistant cassava genotypes. Gelatinization temperature, Peak viscosity, consistency viscosity and stability values of the products ranged from 64.5 ${ }^{\circ} \mathrm{C}$ to $80^{\circ} \mathrm{C}$; $920 \mathrm{BU}$ to $2500 \mathrm{BU} ; 165 \mathrm{BU}$ to 960 $\mathrm{BU}$ and $180 \mathrm{BU}$ to $2190 \mathrm{BU}$ respectively. Values of the functional properties of the starch and lafun samples were also within the range reported in the literature. As expected, the bulk densities of the starch samples were higher than those of the lafun samples. Water and Oil absorption values followed the usual trend, and showed that the cassava genotypes shall find application in the bakery industry. Sensory evaluation of the amala obtained from lafun samples indicated that the smell, hand feel, appearance and the general acceptability of the pastes were adequate.

\section{REFERENCES}

Adeyemi, I.A., Adabiri, B.O., Afolabi, O.A. and Oke, O.L. (1992) Evaluation of some quality characteristics and baking potentials of Amaranth flour. Nig. Food Journal 10: 8-15

Achinewhu S.C. and Orafun J.T (2000) Fufu yield of some improved cassava cultivars and their physico- and sensory properties. Nig. Food J. Vol. 17. 18. p 226-230.

Bokanga, M. and Otoo, E. (1994) Cassava based foods: how safe are they? In: Tropical Root Crops in a Developing Economy. Ofori, F. and Hahn, S.K. (Eds.) proceedings of the ninth Symposium of the International Society for Tropical Root Crops, p 2026 October, Accra, Ghana

Cock, J.H. (1985) Cassava-new potential for a neglected crop. Westview, London, UK.

Ejiofor M.A.N. and Ukpabi U.J. (1997) Cassava Processing for Health: some major advances in Nigeria, p, 22 - 27. 
FAO (1991) Food Outlook, May 1991. FAO Rome

FAO STAT (2002). The World Production of Cassava Roots in 2001, http://www.fao.org

Iwe, M.O. and Onuh, J.O. (1992) Functional and Sensory properties of soybean and sweet potato flour mixtures. Lebensmittelwissenschaft und Technologie, 25: 569-573.

Iwe, M.O., Wolters, I., Gort, G., Stolp, W. and van Zuilichem, D.J. (1999) Behaviour of gelatinization and viscosity in Soy-sweet potato mixtures by singlescrew extrusion: AResponse Surface Analysis.

Iwe, M.O. and Onadipe, O.O. (2001) Effect of addition of extruded full-fat flour into sweet potato flour on the functional properties of the mixture. J.Sustain Agric. Environ. 3(1): 109-117
Iwe, M.O. (2002) Handbook of Sensory Methods and Analysis. Rojoint Communications Services Ltd, Uwani-Enugu Nigeria.

Iwe M.O (2003). The Science and Technology of Soybean. Rojoint Communications Services Ltd Uwani-Enugu Nigeria.

Oguntunde, A.O. (1987) Review: Starch modification for food application. Nig. Food Journal 5: 102-107.

Okezie, B.O and Bello O. (1988) Physicochemical and functional properties of winged bean flour and isolate compared with soy isolate. J. Food Science, 53: 450-454. 
Table 1: Pasting characteristics ${ }^{\mathrm{a}}$ of starch and lafun samples produced from CMD resistant cassava genotypes

\begin{tabular}{|c|c|c|c|c|c|c|c|c|}
\hline \multirow[t]{2}{*}{$\begin{array}{l}\text { Cassava } \\
\text { genotype }\end{array}$} & \multicolumn{2}{|c|}{$\begin{array}{l}\text { Gelatinization } \\
\text { temperature }\left({ }^{\circ} \mathrm{C}\right)\end{array}$} & \multicolumn{2}{|c|}{$\begin{array}{l}\text { Peak viscosity } \\
\operatorname{Tg}\left(V_{m}\right) B U\end{array}$} & \multicolumn{2}{|c|}{$\begin{array}{l}\text { Viscosity at } \\
92^{\circ} \mathrm{C} \text { after } 15 \\
\min \left(V_{r}\right) B U\end{array}$} & \multicolumn{2}{|c|}{$\begin{array}{l}\text { Stability }\left(V_{m-}\right. \\
\left.V_{r}\right) B U\end{array}$} \\
\hline & Starch & Lafun & Starch & Lafun & Starch & Lafun & Starch & Lafun \\
\hline TMS94/0039 & $72.5^{b}$ & $76.00^{\mathrm{cd}}$ & $2245^{\mathrm{d}}$ & $2020^{c}$ & $700^{g}$ & $178^{p}$ & $1545^{\text {fg }}$ & $1842^{c}$ \\
\hline TMS98/0002 & $71.00^{\mathrm{bc}}$ & $79.30^{\mathrm{ab}}$ & $2350 \mathrm{c}$ & $1600^{\mathrm{g}}$ & $880^{\mathrm{b}}$ & $600^{i}$ & $1470^{\mathrm{g}}$ & $1000^{\mathrm{k}}$ \\
\hline TMS92/0057 & $69.50^{\text {cde }}$ & $74.95^{\mathrm{cd}}$ & $2470^{g}$ & $2000^{d}$ & $820^{\mathrm{d}}$ & $200^{c}$ & $1650^{\mathrm{e}}$ & $1800^{\mathrm{d}}$ \\
\hline TMS30572 & $71.00^{\mathrm{bc}}$ & $76.00^{\mathrm{cd}}$ & $2000^{g}$ & $1165^{\mathrm{j}}$ & $800^{\mathrm{e}}$ & $700^{\mathrm{d}}$ & $1200^{\mathrm{h}}$ & $465^{p}$ \\
\hline TMS98/2101 & $68.75^{\mathrm{de}}$ & $74.50^{\mathrm{de}}$ & $2500^{\mathrm{a}}$ & $996^{1}$ & $540^{\mathrm{k}}$ & $165^{\mathrm{q}}$ & $1950^{d}$ & $831^{\mathrm{n}}$ \\
\hline TMS96/1089 & $68.00^{e}$ & $79.95^{\mathrm{a}}$ & $2500^{\mathrm{a}}$ & $2500^{\mathrm{a}}$ & $380^{\circ}$ & $830^{c}$ & $2120^{\mathrm{ab}}$ & $1670^{f}$ \\
\hline TMS99/3073 & $64.50^{\mathrm{f}}$ & $69.00^{\mathrm{g}}$ & $2500^{a}$ & $1700^{\mathrm{f}}$ & $500^{\mathrm{m}}$ & $400^{\mathrm{m}}$ & $2106^{\mathrm{b}}$ & $1200^{\mathrm{h}}$ \\
\hline TMS99/2123 & $74.00^{\mathrm{a}}$ & $80.50^{\mathrm{a}}$ & $2500^{a}$ & $2400^{\mathrm{b}}$ & $550^{i}$ & $630^{\mathrm{g}}$ & $1950^{c}$ & $1770^{\mathrm{e}}$ \\
\hline TMS98/0068 & $70.30^{\mathrm{de}}$ & $72.70^{\text {ef }}$ & $2210^{\mathrm{a}}$ & $2500^{\mathrm{a}}$ & $390^{\mathrm{n}}$ & $354^{\mathrm{n}}$ & $1820^{\mathrm{d}}$ & $2164^{a}$ \\
\hline TMS96/1565 & $72.50^{b}$ & $79.00^{\mathrm{ab}}$ & $2500^{\mathrm{a}}$ & $2500^{a}$ & $890^{a}$ & $645^{\mathrm{f}}$ & $1630^{\mathrm{e}}$ & $1855^{\mathrm{b}}$ \\
\hline NR8082 & $68.00^{\mathrm{e}}$ & $76.30^{\text {ef }}$ & $1350^{k}$ & $1150^{k}$ & $700^{g}$ & $620^{\mathrm{h}}$ & $650^{\mathrm{j}}$ & $530^{\circ}$ \\
\hline TMS95/0166 & $65.50^{\mathrm{f}}$ & $75.50^{\text {cd }}$ & $1020^{1}$ & $920^{\mathrm{m}}$ & $800^{\mathrm{e}}$ & $685^{\mathrm{e}}$ & $220^{k}$ & $235^{\mathrm{r}}$ \\
\hline TMS4(2)1425 & $70.25^{\mathrm{cd}}$ & $76.45^{\mathrm{cd}}$ & $1650^{i}$ & $2000^{\mathrm{d}}$ & $580^{\mathrm{i}}$ & $960^{\mathrm{a}}$ & $1070^{\mathrm{i}}$ & $1140^{\mathrm{i}}$ \\
\hline TMS94/0026 & $71.00^{\mathrm{bc}}$ & $76.00^{\mathrm{cd}}$ & $1690^{\mathrm{i}}$ & $1000^{1}$ & $610^{\mathrm{h}}$ & $628^{\mathrm{g}}$ & $180^{k}$ & $372^{\mathrm{q}}$ \\
\hline TMS94/0561 & $71.00^{\mathrm{bc}}$ & $72.70^{\text {ef }}$ & $2000^{\mathrm{g}}$ & $2500^{a}$ & $520^{1}$ & $860^{b}$ & $1480^{\mathrm{g}}$ & $1640^{g}$ \\
\hline TME419 & $69.20^{d}$ & $76.30^{\text {cd }}$ & $2500^{\mathrm{a}}$ & $1750^{e}$ & $880^{\mathrm{b}}$ & $860^{b}$ & $1620^{\mathrm{ef}}$ & $890^{1}$ \\
\hline M98/0068 & $69.51^{\text {cde }}$ & $79.00^{\mathrm{ab}}$ & $1890^{\mathrm{f}}$ & $2500^{\mathrm{h}}$ & $785^{\mathrm{f}}$ & $560^{\mathrm{j}}$ & $1105^{\mathrm{i}}$ & $860^{\mathrm{m}}$ \\
\hline TMS92B/0068 & $69.15^{\mathrm{de}}$ & $71.50^{\mathrm{f}}$ & $2500^{\mathrm{h}}$ & $1420^{i}$ & $310^{p}$ & $530^{k}$ & $2190^{\mathrm{a}}$ & $890^{1}$ \\
\hline TMS98/0581 & $69.00^{\mathrm{e}}$ & $77.50^{\mathrm{bc}}$ & $2060^{\mathrm{f}}$ & $1460^{\mathrm{h}}$ & $870^{c}$ & $418^{1}$ & $1190^{\mathrm{h}}$ & $1042^{\mathrm{j}}$ \\
\hline M98/0028 & nd & $79.00^{\mathrm{ab}}$ & nd & $1380^{\mathrm{hi}}$ & nd & $840^{\mathrm{bc}}$ & nd & $540^{\circ}$ \\
\hline TMS95/0397 & $65.20^{\mathrm{f}}$ & $72.25^{\text {ef }}$ & $1590^{\circ}$ & $1800^{e}$ & $400^{\mathrm{n}}$ & $220^{\circ}$ & $1190^{\mathrm{h}}$ & $1580^{g}$ \\
\hline TMS97/4779 & nd & $75.00^{c}$ & nd & $2000^{\mathrm{d}}$ & nd & $800^{\mathrm{cd}}$ & nd & $1200^{h}$ \\
\hline TMS98/0505 & $71.70^{\text {cd }}$ & nd & $1490^{\circ}$ & nd & $482^{\mathrm{m}}$ & nd & $1008^{i}$ & nd \\
\hline TMS82/0058 & $67.25^{\mathrm{e}}$ & nd & $2386^{c}$ & nd & $840^{\mathrm{d}}$ & nd & $1546^{\mathrm{fg}}$ & nd \\
\hline TMS96/0603 & $70.00^{\mathrm{de}}$ & nd & $2060^{f}$ & nd & $418^{n}$ & nd & $1642^{\mathrm{e}}$ & nd \\
\hline TMS97/2205 & $68.60^{\mathrm{e}}$ & nd & $2418^{\mathrm{b}}$ & nd & $780^{\mathrm{f}}$ & nd & $1638^{\mathrm{e}}$ & nd \\
\hline TMS98/0510 & $71.00^{\mathrm{bc}}$ & nd & $2445^{b}$ & nd & $640^{\mathrm{h}}$ & nd & $1805^{\mathrm{d}}$ & nd \\
\hline TMS92/0067 & $72.20^{\mathrm{b}}$ & nd & $2440^{b}$ & nd & $660^{\mathrm{h}}$ & nd & $1785^{\mathrm{d}}$ & nd \\
\hline
\end{tabular}

$a=$ Any sample mean followed by the same superscript in the same column is not significantly different $(p>0.05)$

$n d=$ not determined 
Table 2: Functional properties ${ }^{\mathrm{b}}$ of the starch and lafun samples

\begin{tabular}{|c|c|c|c|c|c|c|}
\hline \multirow[t]{2}{*}{ Genotype } & \multicolumn{2}{|c|}{$\begin{array}{l}\text { Bulk density } \\
\left(\mathrm{g} / \mathrm{cm}^{3}\right)\end{array}$} & \multicolumn{2}{|c|}{$\begin{array}{l}\text { Oil absorption } \\
\text { capacity }(\mathrm{g} / \mathrm{ml})\end{array}$} & \multicolumn{2}{|c|}{$\begin{array}{l}\text { Water absorption } \\
\text { capacity }(\mathrm{g} / \mathrm{ml})\end{array}$} \\
\hline & Starch & Lafun & Starch & Lafun & Starch & Lafun \\
\hline TMS 94/0039 & $1.43^{\mathrm{m}}$ & $1.6^{\mathrm{h}}$ & $1.5^{\mathrm{c}}$ & $2.5^{\mathrm{b}}$ & $1.0^{\mathrm{b}}$ & $1.0^{\mathrm{d}}$ \\
\hline TMS 98/0002 & $2.02^{\mathrm{e}}$ & $1.43^{\mathrm{c}}$ & $1.5^{\mathrm{c}}$ & $2.0^{c}$ & $1.0^{\mathrm{b}}$ & $1.1^{\mathrm{d}}$ \\
\hline TMS 92/0057 & $2.00^{\mathrm{e}}$ & $1.11^{\mathrm{g}}$ & $1.5^{\mathrm{c}}$ & $2.0^{c}$ & $1.0^{\mathrm{b}}$ & $1.5^{\mathrm{c}}$ \\
\hline TMS 30572 & $1.77^{\mathrm{hi}}$ & $0.87^{1}$ & $2.0^{c}$ & $1.5^{\mathrm{d}}$ & $1.5^{\mathrm{a}}$ & $2.5^{\mathrm{a}}$ \\
\hline TMS 98/2101 & $1.54^{1}$ & $0.95^{\mathrm{j}}$ & $1.5^{\mathrm{c}}$ & $2.5^{\mathrm{b}}$ & $0.5^{\mathrm{c}}$ & $1.5^{\mathrm{c}}$ \\
\hline TMS 96/1089А & $2.00^{\mathrm{e}}$ & $1.11^{\mathrm{g}}$ & $1.5^{\mathrm{c}}$ & $1.5^{\mathrm{d}}$ & $1.5^{\mathrm{a}}$ & $1.5^{\mathrm{c}}$ \\
\hline TMS 99/3073 & $1.85^{\mathrm{f}}$ & $1.05^{\mathrm{h}}$ & $1.5^{\mathrm{c}}$ & $1.5^{\mathrm{d}}$ & $0.5^{\mathrm{c}}$ & $1.5^{\mathrm{c}}$ \\
\hline TMS 99/2123 & $1.82^{\mathrm{fg}}$ & $1.25 \mathrm{e}$ & $2.5^{\mathrm{a}}$ & $2.5^{\mathrm{b}}$ & $1.0^{\mathrm{b}}$ & $0.5^{\mathrm{e}}$ \\
\hline TMS 98/0068 & $2.03^{\mathrm{e}}$ & $1.33^{\mathrm{d}}$ & $1.5^{\mathrm{c}}$ & $3.0^{\mathrm{a}}$ & $1.0^{\mathrm{b}}$ & $1.5^{\mathrm{c}}$ \\
\hline TMS 96/1565 & $1.70^{\mathrm{j}}$ & $0.80^{\mathrm{n}}$ & $1.5^{\mathrm{c}}$ & $2.5^{\mathrm{b}}$ & $1.5^{\mathrm{a}}$ & $1.5^{\mathrm{c}}$ \\
\hline NR8082 & $2.22^{\mathrm{d}}$ & $0.95^{\mathrm{g}}$ & $1.5^{\mathrm{c}}$ & $2.0^{c}$ & $1.5^{\mathrm{a}}$ & $1.5^{\mathrm{c}}$ \\
\hline TMS 95/0166 & $2.22^{\mathrm{d}}$ & $0.91^{\mathrm{k}}$ & $1.5^{\mathrm{c}}$ & $2.5^{\mathrm{b}}$ & $1.0^{\mathrm{b}}$ & $1.5^{\mathrm{c}}$ \\
\hline TMS 4(2) 1425 & $1.82^{\mathrm{fg}}$ & $0.95^{\mathrm{j}}$ & $1.0^{\mathrm{d}}$ & $2.0^{c}$ & $1.0^{\mathrm{b}}$ & $1.5^{\mathrm{c}}$ \\
\hline TMS 94/0026 & $1.80^{\text {gh }}$ & $1.00^{\mathrm{i}}$ & $1.5^{\mathrm{c}}$ & $1.5^{\mathrm{d}}$ & $1.0^{\mathrm{b}}$ & $1.5^{\mathrm{c}}$ \\
\hline TMS 94/0561 & $2.50^{c}$ & $0.87^{1}$ & $1.5^{\mathrm{c}}$ & $2.5^{\mathrm{b}}$ & $1.5^{\mathrm{a}}$ & $2.0^{\mathrm{b}}$ \\
\hline TME419 & $1.82^{\mathrm{fg}}$ & $1.25^{\mathrm{e}}$ & $1.5^{\mathrm{c}}$ & $1.5^{\mathrm{d}}$ & $1.0^{\mathrm{b}}$ & $1.0^{\mathrm{d}}$ \\
\hline M98/0068 & $3.33^{\mathrm{a}}$ & $1.05^{\mathrm{h}}$ & $1.5^{\mathrm{c}}$ & $2.0^{\mathrm{c}}$ & $1.0^{\mathrm{ab}}$ & $1.0^{\mathrm{d}}$ \\
\hline TMS 92B/0068 & $1.82^{\mathrm{fg}}$ & $1.18^{\mathrm{e}}$ & $1.5^{\mathrm{c}}$ & $2.0^{c}$ & $1.0^{\mathrm{ab}}$ & $1.5^{\mathrm{d}}$ \\
\hline TMS 98/0581 & $1.55^{1}$ & $0.95^{\mathrm{j}}$ & $1.5^{\mathrm{c}}$ & $2.0^{c}$ & $1.5^{\mathrm{a}}$ & $1.5^{\mathrm{c}}$ \\
\hline M98/0028 & $2.86^{\mathrm{b}}$ & $1.05^{\mathrm{h}}$ & $1.5^{\mathrm{c}}$ & $2.5^{\mathrm{a}}$ & $1.0^{\mathrm{b}}$ & $2.0^{\mathrm{b}}$ \\
\hline TMS 95/0397 & $1.61^{\mathrm{k}}$ & $0.91^{\mathrm{k}}$ & $1.5^{\mathrm{c}}$ & $2.5^{\mathrm{b}}$ & $1.0^{\mathrm{b}}$ & $2.0^{\mathrm{b}}$ \\
\hline TMS 97/4779 & $1.75^{\mathrm{i}}$ & $0.95^{\mathrm{j}}$ & $1.5^{\mathrm{c}}$ & $1.5^{\mathrm{d}}$ & $1.0^{\mathrm{b}}$ & $1.5^{\mathrm{c}}$ \\
\hline TMS 98/0505 & $1.54^{1}$ & $0.84^{\mathrm{m}}$ & $1.5^{\mathrm{c}}$ & $2.5^{\mathrm{b}}$ & $1.0^{\mathrm{b}}$ & $1.5^{\mathrm{c}}$ \\
\hline TMS 82/0058 & $1.25^{\mathrm{n}}$ & $0.65^{\mathrm{p}}$ & $1.5^{\mathrm{c}}$ & $1.5^{\mathrm{d}}$ & $1.0^{\mathrm{b}}$ & $1.5^{\mathrm{c}}$ \\
\hline TMS 96/0603 & $1.54^{1}$ & $0.74^{\circ}$ & $1.5^{\mathrm{c}}$ & $1.5^{\mathrm{d}}$ & $1.0^{\mathrm{c}}$ & $1.5^{\mathrm{c}}$ \\
\hline TMS 97/2205 & $1.43^{\mathrm{m}}$ & $0.83^{\mathrm{m}}$ & $1.5^{\mathrm{c}}$ & $2.0^{c}$ & $1.5^{\mathrm{c}}$ & $2.0^{\mathrm{b}}$ \\
\hline TMS 98/0510 & $2.22^{\mathrm{d}}$ & $1.52^{\mathrm{b}}$ & $2.0^{b}$ & $2.5^{\mathrm{b}}$ & $1.5^{\mathrm{b}}$ & $1.5^{\mathrm{c}}$ \\
\hline TMS 92/0067 & $2.86^{\mathrm{b}}$ & $1.96^{\mathrm{a}}$ & $1.5^{\mathrm{c}}$ & $1.5^{\mathrm{d}}$ & $1.0^{\mathrm{c}}$ & $1.5^{\mathrm{c}}$ \\
\hline
\end{tabular}

$b=$ Any sample mean followed by the same superscript in the column is not significantly different $(p>0.05)$ 
Pasting and functional properties of lafun and starch processed from cassava genotypes.

Omodamiro et al.

Table 3: Sensory evaluation scores $^{\mathrm{c}}$ of amala prepared from lafun samples

\begin{tabular}{|c|c|c|c|c|}
\hline Cassava genotype & Smell & Handfeel (stickiness) & Appearance & General acceptance \\
\hline TMS94/0039 & $5.96^{\mathrm{a}}$ & $5.56^{\mathrm{a}}$ & $5.72^{\mathrm{a}}$ & $5.92^{\mathrm{a}}$ \\
\hline TMS98/0002 & $5.12^{\mathrm{abc}}$ & $5.08^{\mathrm{bcd}}$ & $5.00^{\mathrm{abcd}}$ & $5.3^{\mathrm{bcd}}$ \\
\hline TMS92/0057 & $5.24^{\mathrm{abc}}$ & $4.46^{\mathrm{bcd}}$ & $4.84^{\text {abcd }}$ & $4.92^{\mathrm{bcd}}$ \\
\hline TMS30572 & $5.44^{\mathrm{ab}}$ & $5.48^{\mathrm{ab}}$ & $5.32^{\mathrm{abc}}$ & $5.36^{\mathrm{ab}}$ \\
\hline TMS98/2101 & $4.72^{\mathrm{bc}}$ & $3.80^{\mathrm{de}}$ & $4.12^{\mathrm{d}}$ & $4.36^{\mathrm{d}}$ \\
\hline TMS96/1089 & $5.40^{\mathrm{ab}}$ & $4.56^{\mathrm{bcd}}$ & $4.96^{\mathrm{abcd}}$ & $4.96^{\mathrm{bcd}}$ \\
\hline TMS99/3073 & $4.80^{\mathrm{bc}}$ & $3.70^{\mathrm{e}}$ & $4.76^{\mathrm{bcd}}$ & $4.44^{\mathrm{cd}}$ \\
\hline TMS99/2123 & $4.84^{\mathrm{bc}}$ & $4.44^{\text {cde }}$ & $5.28^{\mathrm{abc}}$ & $4.96^{\mathrm{bcd}}$ \\
\hline TMS98/006 & $5.24^{\mathrm{abc}}$ & $4.56^{\mathrm{bcd}}$ & $5.60^{\mathrm{ab}}$ & $5.32^{\mathrm{abc}}$ \\
\hline TMS96/1565 & $4.52^{\mathrm{c}}$ & $3.76^{\mathrm{e}}$ & $4.48^{\mathrm{dc}}$ & $4.28^{\mathrm{d}}$ \\
\hline NR8082 & $4.72^{\mathrm{bc}}$ & $4.20^{\text {cde }}$ & $4.60^{\mathrm{dc}}$ & $4.76^{\mathrm{bcd}}$ \\
\hline TMS95/0166 & $5.24^{\mathrm{abc}}$ & $4.28^{\mathrm{cde}}$ & $5.24^{\mathrm{dc}}$ & $5.44^{\mathrm{ab}}$ \\
\hline TMS4(2) 1425 & $5.08^{\mathrm{bc}}$ & $4.16^{\text {cde }}$ & $4.92^{\text {abcd }}$ & $5.12^{\text {abcd }}$ \\
\hline TMS94/0026 & $5.20^{\mathrm{abc}}$ & $4.40^{\text {cde }}$ & $4.68^{\mathrm{dc}}$ & $4.60^{\mathrm{bcd}}$ \\
\hline TMS94/0561 & $5.04^{\mathrm{bc}}$ & $4.76^{\mathrm{bcd}}$ & $5.12^{\mathrm{abc}}$ & $5.28^{\mathrm{abc}}$ \\
\hline TME419 & $5.12^{\mathrm{abc}}$ & $4.08^{\mathrm{de}}$ & $4.96^{\mathrm{abcd}}$ & $4.64^{\mathrm{bcd}}$ \\
\hline
\end{tabular}

$c=$ Scores with the same superscript in a column are not significantly different $(p>0.05)$ using Duncan's Multiple Range Test. 